\title{
THE BLOOD LIPIDS OF DIABETIC CHILDREN ${ }^{1}$
}

\author{
By I. L. CHAIKOFF, FRANCIS S. SMYTH AND G. E. GIBBS \\ (From the Division of Pediatrics, San Francisco, and the Division of Physiology, Berkeley, \\ of the University of California Medical School)
}

(Received for publication June 16, 1936)

The development of degenerative changes in the cardiovascular system in diabetes has focused attention in recent years on the lipid metabolism of diabetes in childhood, a period in which diabetes occurs in a less complicated form than in the adult. Despite the fact that satisfactory evidence is still lacking for proof, there is a belief that the arteriosclerosis observed today even in the young diabetic is related to the cholesterol level of the blood. The growing importance of the diabetic child, particularly since today he provides a source from which the adult diabetic is recruited, makes highly desirable the accumulation of data on various aspects of his lipid metabolism. In the present investigation, therefore, a study has been made of all blood lipid constituents, namely, total fatty acids, phospholipids, and free and esterified cholesterol, in diabetic children under controlled conditions. Although lipids in the blood of diabetic children have previously been reported $(1,2,3)$, these studies are few in number. Some of them have employed unsatisfactory methods or have dealt with a single lipid constituent, i.e., total cholesterol, which a number of workers regard as an index of the level of other lipid constituents in the blood.

\section{EXPERIMENTAL}

Forty-nine children were employed in this study. Twenty-three of them were non-diabetic and were used to establish the normal lipid level. The latter were school children who came to the Outpatient Department for routine tests, and in whom no abnormalities-unless otherwise recorded-were found by clinical examinations. No attempt was made to regulate the diet or nutritional state of these normal subjects other than

\footnotetext{
1 Aided by a grant from the Pauline Fore Moffitt Fund for the study of Juvenile Diabetes.
}

withholding all food for approximately 12 to 14 hours prior to removal of the blood sample.

In 3 cases blood was obtained from the diabetic children at a time when acidosis was present. The remainder of the observations, 26 in all, were made on children under adequate insulin and dietary control. At the time blood was taken for lipid analyses these patients had either been hospitalized for some time or been admitted for a single day for routine laboratory and physical examination as well as for regulation of diet and insulin dosage, a procedure that was carried out at intervals of 2 or 3 months.

Whole blood was used for lipid analyses, and the oxidative methods employed have been previously reported (4). The determinations of blood lipids were carried out in triplicate; the values recorded are the averages of closely agreeing figures.

Okey and Stewart (5) pointed out several years ago that irregularities in the effects produced by anticoagulants and centrifugation make plasma less desirable than whole blood for comparative lipid studies. The errors introduced in the lipid determinations of plasma obtained by the use of oxalate have been studied more recently by Schmidt (6) and by Sperry and Schoenheimer (7), who have shown that oxalated blood plasma contains smaller amounts of phospholipids and cholesterol than heparinized plasma. Despite the unequal distribution of cholesterol between plasma and corpuscles, there seems little justification at the present time for the claim that plasma or serum provides a more significant medium for lipid determination than whole blood. Too little is known of the rôle of the corpuscles in lipid metabolism, particularly in pathological conditions. Hence, in the present investigation, whole blood was used throughout for the comparison of the lipid content of the blood of normal and diabetic children. 
TABLE I

Whole blood lipids (postabsorptive) of controlled diabetic children

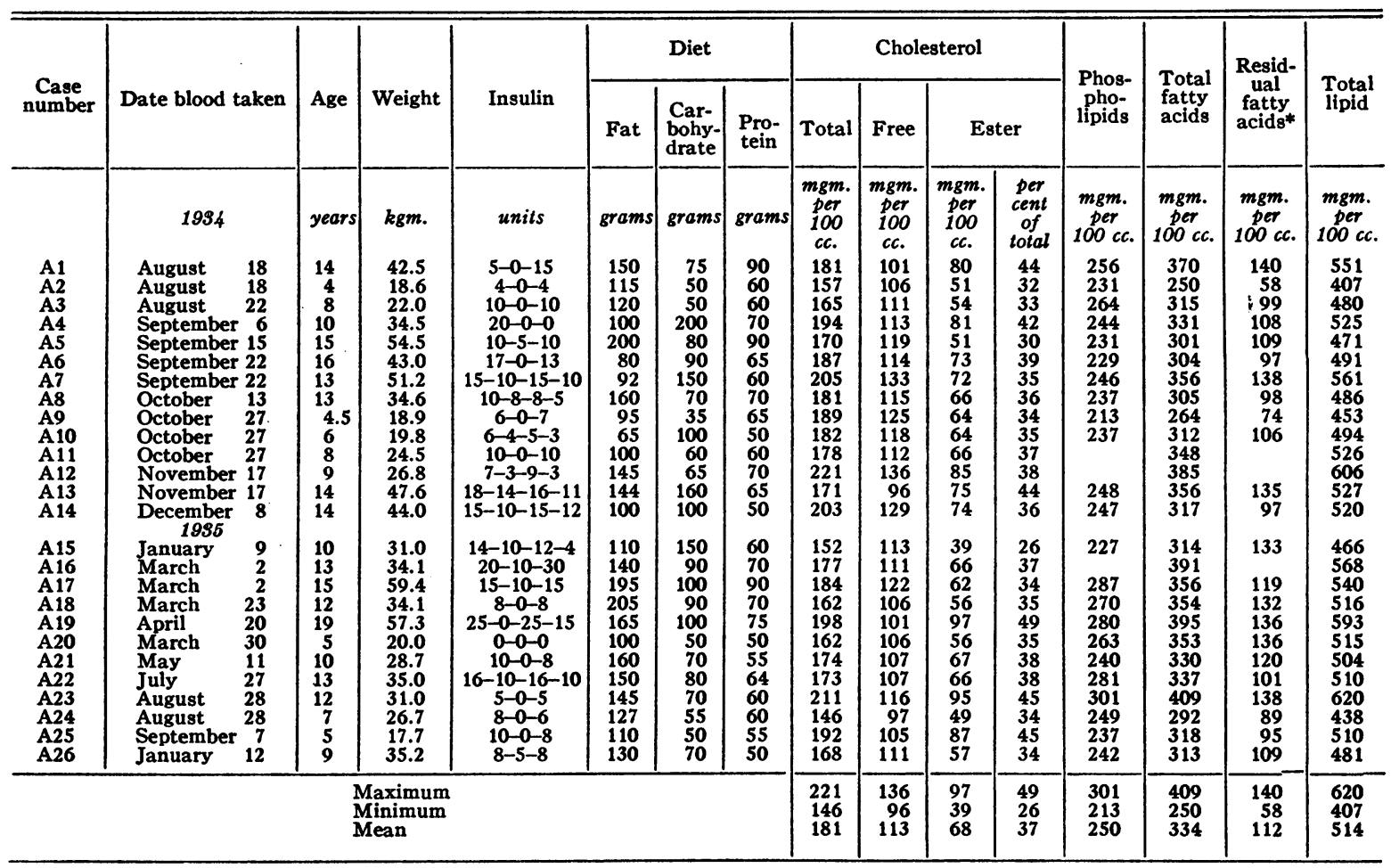

* Derived chiefly from neutral fat.

\section{RESULTS}

The various lipid constituents determined in the whole blood of normal children are shown in Table II, whereas the values for the diabetic children are recorded in Tables I and III. The results obtained for the latter may be grouped according to the degree of control effected by insulin and diet.

1. Controlled diabetic children. The concentration of all lipid constituents that was found in the blood of the controlled diabetics corresponded closely to the normal range. Thus the maximum and minimum values for total lipids were respectively 620 and $407 \mathrm{mgm}$. per cent as compared with values of 595 and $417 \mathrm{mgm}$. observed in normal subjects. The total fatty acid content of the blood of diabetic children varied from 409 to $250 \mathrm{mgm}$. per cent, whereas the highest and lowest values for this constituent in the normal children were respectively 387 and $260 \mathrm{mgm}$. per cent. The phospholipid values fluctuated between 301 and $213 \mathrm{mgm}$. in the diabetic and between 288 and 184 in the normal children. The close agreement between the cholesterol values of normal and diabetic subjects is particularly striking. Total cholesterol, which was present to the extent of 226 to $141 \mathrm{mgm}$. per $100 \mathrm{cc}$. of the blood of the normal children, ranged from 221 to $146 \mathrm{mgm}$. per cent in the diabetics; the free or uncombined portion of this consisted of 131 to 91 in the nondiabetics and 136 to 96 in the diabetics. The mean values obtained for both groups of children are also in close agreement.

2. Diabctic children in acidosis. Although this study was concerned primarily with children under control, blood lipids were also obtained from 3 cases suffering from diabetic acidosis (Table III). In 2 of these (A19 and A21) the postabsorptive blood samples obtained during acidosis contained a much higher concentration of total lipids than samples taken during periods in which these patients were under control. The various lipid constituents, however, did not share equally in this rise of the total lipid. While no increase in cholesterol was found in A21 during acidosis, in A19 it rose from a controlled level of 
BLOOD LIPIDS OF DIABETIC CHILDREN

TABLE II

Whole blood lipids (postabsorptive) of non-diabetic children

\begin{tabular}{|c|c|c|c|c|c|c|c|c|c|c|c|}
\hline \multirow{2}{*}{$\begin{array}{c}\text { Case } \\
\text { number }\end{array}$} & \multirow{2}{*}{$\begin{array}{l}\text { Date blood } \\
\text { taken }\end{array}$} & \multirow{2}{*}{ Age } & \multirow{2}{*}{ Weight } & \multicolumn{4}{|c|}{ Cholesterol } & \multirow{2}{*}{$\begin{array}{l}\text { Phospho- } \\
\text { lipids }\end{array}$} & \multirow{2}{*}{$\begin{array}{l}\text { Total } \\
\text { fatty } \\
\text { acids }\end{array}$} & \multirow{2}{*}{$\begin{array}{l}\text { Residual } \\
\text { fatty } \\
\text { acids }\end{array}$} & \multirow{2}{*}{$\begin{array}{l}\text { Total } \\
\text { lipid }\end{array}$} \\
\hline & & & & Total & Free & \multicolumn{2}{|c|}{ Ester } & & & & \\
\hline $\begin{array}{l}\text { C3 } \\
C 4 \\
C 5 \\
C 6 \\
C 7 \\
C 8 \\
C 9 \\
C 10 \\
C 11 \\
C 12 \\
C 13 \\
C 14 \\
C 15 \\
C 16 \\
C 17 \\
C 18 \\
C 19 \\
C 22 \\
C 21 \\
C 22 \\
C 24 \\
C 25 \\
C 26\end{array}$ & \begin{tabular}{lr}
\multicolumn{2}{c}{1995} \\
Feb. & 9 \\
Feb. & 9 \\
Feb. & 9 \\
Feb. & 16 \\
April & 13 \\
April & 20 \\
July & 7 \\
July & 7 \\
Aug. & 3 \\
Sept. 7 \\
Sept. 7 \\
Sept. 21 \\
Sept. 21 \\
Oct. 26 \\
Nov. 18 \\
Nov. 25 \\
Nov. 25 \\
Nov. 25 \\
Dec. 16 \\
Dec. 16 \\
Dec. 23 \\
Dec. 23 \\
Dec. 23
\end{tabular} & $\begin{array}{c}\text { years } \\
13 \\
6 \\
5 \\
14 \\
13 \\
15 \\
4 \\
8 \\
13 \\
15 \\
7 \\
5 \\
9 \\
10 \\
12 \\
12 \\
13 \\
11 \\
12 \\
9 \\
4 \\
7 \\
6\end{array}$ & $\begin{array}{l}k g m . \\
\\
21.6 \\
17.7 \\
45.1 \\
47.2 \\
49.5 \\
17.2 \\
25.2 \\
38.4 \\
47.2 \\
20.9 \\
15.8 \\
27.5 \\
30.0 \\
31.8 \\
34.6 \\
35.6 \\
35.2 \\
36.0 \\
29.3 \\
14.7 \\
23.6 \\
19.7\end{array}$ & $\begin{array}{c}\text { mgm. per } \\
100 \text { cc. } \\
146 \\
198 \\
162 \\
173 \\
164 \\
141 \\
154 \\
152 \\
141 \\
158 \\
183 \\
176 \\
181 \\
174 \\
161 \\
150 \\
172 \\
150 \\
208 \\
164 \\
169 \\
198 \\
226\end{array}$ & $\begin{array}{c}\text { mgm. per } \\
100 \text { cc. } \\
96 \\
131 \\
107 \\
105 \\
105 \\
91 \\
105 \\
100 \\
94 \\
95 \\
107 \\
96 \\
104 \\
104 \\
108 \\
98 \\
94 \\
100 \\
126 \\
96 \\
92 \\
109 \\
122\end{array}$ & $\begin{array}{c}\text { mgm. per } \\
100 \text { cc. } \\
50 \\
67 \\
55 \\
68 \\
59 \\
50 \\
49 \\
52 \\
47 \\
63 \\
76 \\
80 \\
77 \\
70 \\
53 \\
52 \\
78 \\
50 \\
82 \\
68 \\
77 \\
89 \\
104\end{array}$ & 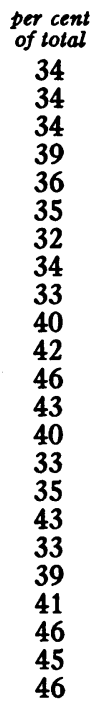 & $\begin{array}{c}\text { mgm. per } \\
100 \text { cc. } \\
240 \\
254 \\
253 \\
217 \\
268 \\
222 \\
259 \\
273 \\
249 \\
230 \\
278 \\
219 \\
240 \\
248 \\
220 \\
184 \\
186 \\
186 \\
270 \\
288 \\
218 \\
214 \\
212\end{array}$ & $\begin{array}{c}\text { mgm. per } \\
100 \text { cc. } \\
277 \\
325 \\
297 \\
318 \\
304 \\
279 \\
320 \\
325 \\
276 \\
323 \\
298 \\
334 \\
260 \\
280 \\
279 \\
313 \\
288 \\
290 \\
387 \\
338 \\
261 \\
336 \\
283\end{array}$ & $\begin{array}{c}\text { mgm. per } \\
100 \text { cc. } \\
80 \\
106 \\
88 \\
123 \\
81 \\
93 \\
110 \\
104 \\
75 \\
123 \\
57 \\
129 \\
43 \\
63 \\
93 \\
152 \\
107 \\
129 \\
147 \\
95 \\
58 \\
127 \\
66\end{array}$ & $\begin{array}{c}\text { mgm. per } \\
100 \text { cc. } \\
423 \\
523 \\
459 \\
491 \\
468 \\
420 \\
474 \\
477 \\
417 \\
481 \\
481 \\
510 \\
441 \\
454 \\
440 \\
463 \\
460 \\
440 \\
595 \\
502 \\
430 \\
534 \\
509\end{array}$ \\
\hline \multicolumn{4}{|c|}{$\begin{array}{l}\text { Maximum } \\
\text { Minimum } \\
\text { Mean }\end{array}$} & $\begin{array}{l}226 \\
141 \\
170\end{array}$ & $\begin{array}{r}131 \\
91 \\
104\end{array}$ & $\begin{array}{r}104 \\
47 \\
66\end{array}$ & $\begin{array}{l}46 \\
32 \\
38\end{array}$ & $\begin{array}{l}288 \\
184 \\
236\end{array}$ & $\begin{array}{l}387 \\
260 \\
304\end{array}$ & $\begin{array}{r}152 \\
43 \\
98\end{array}$ & $\begin{array}{l}595 \\
417 \\
474\end{array}$ \\
\hline
\end{tabular}

198 to 238 mgm. per cent during acidosis. But lesterol ester or phospholipid content of the blood it should be noted that the latter value does not during acidosis were neither marked nor conrepresent a significant rise above the highest normal, namely 226 , or for that matter above the highest value found in the controlled diabetics, sistent in these 2 cases.

A6 was brought into control by means of a daily injection of 42 units of insulin and a diet namely $221 \mathrm{mgm}$. per cent. Changes in the cho- containing 90 grams of fat, 84 grams of carbo-

TABLE III

Blood lipids of diabetic children in acidosis. (Blood samples taken in the postabsorptive state unless otherwise stated)

\begin{tabular}{|c|c|c|c|c|c|c|c|c|c|c|c|c|c|c|}
\hline \multirow{2}{*}{$\begin{array}{c}\text { Case } \\
\text { number }\end{array}$} & \multirow{2}{*}{ Date } & \multirow{2}{*}{ Condition } & \multicolumn{4}{|c|}{ Cholesterol } & \multirow{2}{*}{$\begin{array}{c}\text { Phos- } \\
\text { pho- } \\
\text { lipid }\end{array}$} & \multirow{2}{*}{$\begin{array}{l}\text { Total } \\
\text { fatty } \\
\text { acids }\end{array}$} & \multirow{2}{*}{$\begin{array}{c}\text { Resid- } \\
\text { ual } \\
\text { fatty } \\
\text { acids }\end{array}$} & \multirow{2}{*}{$\begin{array}{l}\text { Total } \\
\text { lipid }\end{array}$} & \multirow{2}{*}{$\begin{array}{l}\text { Insu- } \\
\text { lin }\end{array}$} & \multicolumn{3}{|c|}{ Diet } \\
\hline & & & Total & Free & Es & ter & & & & & & Fat & $\begin{array}{c}\text { Car- } \\
\text { bohy- }\end{array}$ & Pro- \\
\hline A6 & $\begin{array}{lr}\text { July } & 13,1935 \\
\text { July } & 20,1935 \\
\text { July } & 25,1935 \\
\text { July } & 26,1935 \\
\text { July } & 27,1935 \\
\text { August } & 3,1935 \\
\text { August } & 28,1936 \\
\text { September } 7,1936 \\
\text { October } & 5,1936\end{array}$ & $\begin{array}{l}\text { Controlled } \\
\text { Acidosis } \\
\text { Acidosis* } \\
\text { Acidosis } \\
\text { No acidosis } \\
\text { No acidosis } \\
\text { Controlled } \\
\text { Controlled } \\
\text { Controlled }\end{array}$ & $\begin{array}{c}\text { mgm. } \\
\text { per } \\
100 \text { cc. } \\
163 \\
182 \\
196 \\
174 \\
193 \\
184 \\
170 \\
160 \\
159\end{array}$ & $\begin{array}{c}\text { mgm. } \\
\text { per } \\
100 \mathrm{cc} . \\
101 \\
112 \\
113 \\
116 \\
116 \\
113 \\
109 \\
98 \\
97\end{array}$ & $\begin{array}{c}\text { mgm. } \\
\text { per } \\
100 \text { cc. } \\
62 \\
70 \\
83 \\
58 \\
77 \\
71 \\
61 \\
62 \\
62\end{array}$ & $\begin{array}{c}\text { per cent } \\
\text { of } \\
\text { total } \\
38 \\
38 \\
42 \\
33 \\
40 \\
39 \\
36 \\
39 \\
39\end{array}$ & $\begin{array}{c}\text { mgm. } \\
\text { per } \\
100 \text { cc. } \\
258 \\
281 \\
389 \\
289 \\
291 \\
281 \\
278 \\
264 \\
261\end{array}$ & $\begin{array}{c}\text { mgm. } \\
\text { per } \\
100 \text { cc. } \\
319 \\
359 \\
969 \\
356 \\
375 \\
\\
356 \\
313 \\
322\end{array}$ & $\begin{array}{c}\text { mgm. } \\
\text { per } \\
100 \mathrm{cc} . \\
101 \\
120 \\
648 \\
120 \\
124 \\
125 \\
92 \\
102\end{array}$ & $\begin{array}{c}\text { mgm. } \\
\text { per } \\
100 c c . \\
482 \\
541 \\
1165 \\
530 \\
568 \\
\\
526 \\
473 \\
481\end{array}$ & $\begin{array}{c}\text { units } \\
42 \\
48 \\
18 \\
26 \\
95 \\
40 \\
56 \\
82 \\
42 \\
24\end{array}$ & $\begin{array}{c}\text { grams } \\
90 \\
90 \\
90 \\
90 \\
90 \\
90 \\
90 \\
40 \\
67\end{array}$ & $\begin{array}{r}\text { grams } \\
\\
84 \\
84 \\
84 \\
84 \\
84 \\
84 \\
84 \\
120 \\
60\end{array}$ & $\begin{array}{c}\text { grams } \\
\\
74 \\
74 \\
74 \\
74 \\
74 \\
74 \\
74 \\
74 \\
74\end{array}$ \\
\hline A19 & $\begin{array}{ll}\text { March } & 30,1935 \\
\text { April } & 20,1935\end{array}$ & $\begin{array}{l}\text { Acidosis } \\
\text { Controlled }\end{array}$ & $\begin{array}{l}238 \\
198\end{array}$ & $\begin{array}{l}129 \\
101\end{array}$ & $\begin{array}{r}109 \\
97\end{array}$ & $\begin{array}{l}46 \\
49\end{array}$ & $\begin{array}{l}268 \\
280\end{array}$ & $\begin{array}{l}730 \\
395\end{array}$ & $\begin{array}{l}470 \\
136\end{array}$ & $\begin{array}{l}968 \\
593\end{array}$ & 65 & $\begin{array}{l}75 \\
75\end{array}$ & $\begin{array}{l}100 \\
100\end{array}$ & $\begin{array}{l}75 \\
75\end{array}$ \\
\hline A21 & $\begin{array}{ll}\text { April } & 29,1935 \\
\text { May } & 11,1935\end{array}$ & $\begin{array}{l}\text { Acidosis } \\
\text { Controlled }\end{array}$ & $\begin{array}{l}165 \\
174\end{array}$ & $\begin{array}{l}104 \\
107\end{array}$ & $\begin{array}{l}61 \\
67\end{array}$ & $\begin{array}{l}37 \\
38\end{array}$ & $\begin{array}{l}296 \\
240\end{array}$ & $\begin{array}{l}576 \\
330\end{array}$ & $\begin{array}{l}333 \\
120\end{array}$ & $\begin{array}{l}742 \\
504\end{array}$ & 20 & $\begin{array}{l}160 \\
160\end{array}$ & $\begin{array}{l}70 \\
70\end{array}$ & $\begin{array}{l}55 \\
55\end{array}$ \\
\hline
\end{tabular}


hydrate and 74 grams of protein. From July 14 to 27 the insulin was gradually reduced so that by July 18 he was receiving 18 units, and this was continued until July 25 . Blood lipids were examined on 3 different occasions during the period in which the patient showed acetonuria. Slight rises in total cholesterol occurred, but these were in no way marked when compared with the values obtained several days later when the patient was free of acetonuria. Indeed, the highest value observed during acidosis was $30 \mathrm{mgm}$. per cent below the highest figure found among the normal children. In 2 of the 3 blood samples taken during acidosis (July 20 and 26) small increases were noted in phospholipids and neutral fat. But again, if these values are compared with those obtained a few days later when the acidosis had disappeared, or with the highest values obtained in the normal subjects, it is questionable whether much significance can be attached to such increases. A striking rise in these 2 lipid constituents did occur, however, in the blood examined at the height of acidosis (July 25), but since this sample was obtained at 3 p.m. instead of in the postabsorptive state, it is difficult to differentiate between the effects of the 2 previous meals and those of the acidosis. It should be noted, however, that, as judged by previous observations made in this laboratory, such increases in neutral fat are not encountered in a normal alimentary lipemia (8).

\section{DISCUSSION AND SUMMARY}

The frequency with which the diabetes of the adult and elderly subject is associated with other pathological conditions makes difficult the interpretation of studies made in these age periods. This difficulty, however, is not so frequently met in the diabetes of childhood. In the group of diabetic children reported in this investigation, abnormalities other than diabetes were not present at the time lipid studies were made. The diabetic child thus provides the most satisfactory patient from whom metabolic disturbances due to diabetes per se may be deduced. The results of the present study show quite definitely that, when controlled by insulin and diet, diabetic children have blood lipid levels well within the normal range. This was found to be the case with all lipid constituents, i.e., free and esterified cholesterol, phospholipids and fatty acids. Normal lipid values were found whether the diabetes was of 3 months' or 3 years' duration, and whether the subject required 68 or 10 units of insulin. These observations on children are thus in accord with the results recently reported by Man and Peters (9) for adult and elderly patients. They found no relation between serum cholesterol and the severity of the diabetes as judged by insulin requirement or carbohydrate tolerance.

From a comparison of the values obtained from 3 patients during acidosis and control, it is apparent that a pronounced increase in the cholesterol content of the blood need not accompany mild acidosis in diabetic children. In no case during acidosis was a value found significantly above the highest normal. Despite the fact that a high cholesterol level has been suggested as a precursor of complications, nevertheless a number of observations now indicate that the cholesterol content of the blood is not a reliable index of the degree of control in diabetes. Thus in 65 of their 94 cases of acidosis, White and Joslin (10) found cholesterol values within or slightly above the normal range. Moreover, Man and Peters (11) have shown that cholesterol falls below the acidosis level during the period immediately following the disappearance of acidosis and dehydration, and that at this time the cholesterol content of the blood may be even lower than at the end of convalescence.

While neutral fat, the changes in which are reflected in the total fatty acid determination, fluctuated widely at times, commensurate changes did not always occur in the cholesterol fraction. The most striking example of this was found in A6 and A21 (Table III). Over a period of 5 days, residual fatty acids rose from 120 to $648 \mathrm{mgm}$. per cent (A6) at the same time that total cholesterol rose from 182 to $196 \mathrm{mgm}$. Although 2 days later residual fatty acids dropped to 124 , cholesterol still remained practically unchanged. A similar lack of relation between cholesterol and total fatty acids has been observed by others $(11,12)$. It follows, therefore, that cholesterol cannot be employed as a guide for the level of other lipid constituents in the blood. 


\section{BIBLIOGRAPHY}

1. White, P., and Hunt, H., Cholesterol of the blood of diabetic children. New England J. Med., 1930, 202, 607.

2. Rabinowitch, I. M., The cholesterol content of blood plasma in juvenile diabetes. A statistical study. Arch. Int. Med., 1929, 43, 372.

3. Boyd, G. L., Blood fat in diabetic children. Am. J. Dis. Child., 1928, 36, 298.

4. Chaikoff, I. L., and Kaplan, A., The blood lipids in completely depancreatized dogs maintained with insulin. J. Biol. Chem., 1934, 106, 267.

5. Okey, R., and Stewart, D., Diet and blood cholesterol in normal women. J. Biol. Chem., 1933, 99, 717.

6. Schmidt, L. H., The nature of the difference in phospholipid content of oxalated and heparinized plasma. J. Biol. Chem., 1935, 109, 449.
7. Sperry, W. M., and Schoenheimer, R., A comparison of serum, heparinized plasma, and oxalated plasma in regard to cholesterol content. J. Biol. Chem., $1935,110,655$.

8. Chaikoff, I. L., McGavack, T. H., and Kaplan, A., The blood lipids in the postabsorptive state and after the ingestion of fat in normal human subjects and in a case of disseminated cutaneous xanthomata. J. Clin. Invest., 1934, 13, 1.

9. Man, E. B., and Peters, J. P., Serum lipoids in diabetes. J. Clin. Invest., 1935, 14, 579.

10. Joslin, E. P., The Treatment of Diabetes Mellitus. Lea and Febiger, Philadelphia, 1935, 5th ed., p. 131.

11. Man, E. B., and Peters, J. P., Lipoids of serum in diabetic acidosis. J. Clin. Invest., 1934, 13, 237.

12. Man, E. B., and Gildea, E. F., Serum lipoids in malnutrition. J. Clin. Invest., 1936, 15, 203. 